\title{
KONFLIK ETNIS DAN AGAMA DI INDONESIA
}

\author{
Suheri Harahap \\ Dosen Prodi Sosiologi Agama Fakultas Ilmu Sosial \\ UIN Sumatera Utara
}

\begin{abstract}
Abstrak
Artikel ini berusaha menguraikan bagaimana konflik etnis dan agama di indonesa kontemporer. Dibeberapa wilayah di Indonesia konflik bernuansa etnis dan agama muncul sebagai respon atas dinamika politik, sosial dan ekonomi yang turut serta mengitari kehidupan sosial masyarakat. belajar adalah manusia yang tidak jatuh pada lubang yang sama. Konflik yang terjadi yang berwujud wilayah rusuh di Indonesia merupakan akumulasi dari kerapuhan persatuan dan kesatuan warga masyarakat heterogen dalam satuan-satuan wilayah kebudayaan dengan kepentingan konspirasi kelompok-kelompok tertentu di dalam negeri serta pihak asing. Kepentingan itu dilaterbelakangi tujuan politik, ekonomi dan agama. Upaya itu tidak mencapai sasaran puncak karena ditingkat elit dan pelaksana pihak keamanan dan birokrasi mayoritas masih komit dengan negara kesatuan sehingga serius memperkecil zona konflik dan kefatalan pelbagai dampaknya. Masyarakat dari berbagai suku dan agama juga tidak memiliki basic yang kuat memasuki kancah konflik bahkan sebaliknya dari semula sudah terbiasa hidup rukun dan damai dalam pelbagai perbedaan. Namun begitu karena masyarakat telah semakin berpendidikan dan cerdas, ditambah dengan nuansa reformasi secara mencuatnya konsep HAM, mereka menginginkan agar pelbagai pihak yang terkait dengan pembangunan.
\end{abstract}

Kata kunci: Konflik Etnik, Konflik Agama, Resolusi Konflik

\section{A. Pengertian Tentang Konflik}

Konflik adalah setiap pertentangan atau perbedaan pendapat antara paling tidak dua orang atau kelompok. ${ }^{1}$ Defenisi konflik yang disebutkan oleh Rauf sejalan dengan pengertian konflik yang digunakan secara luas lembaga seperti The British Council yang menyebut konflik adalah hubungan antara dua pihak atau lebih (individu atau kelompok) yang memiliki atau merasa memiliki

\footnotetext{
${ }^{1}$ Rauf, Maswadi, Konsensus Politik. Jakarta: Direktoral Jenderal Pendidikan Tinggi Departeman Pendidikan Nasional, 2000, hlm.2.
} 
sasaran-sasaran yang tidak sejalan. ${ }^{2}$ Menurut Dean G. Pruit dan Jeffrey Z. Rubin dengan mengangkat pendapat Webster (1966) bahwa istilah "conflict" di dalam bahasa lokalnya berarti suatu perkelahian, peperangan atau perjuangan yaitu berupa konfrontasi fisik antara beberapa pihak. Olehnya disebutkan bahwa pengertian tersebut mengalami perkembangan sehingga menyentuh aspek psikologi sehingga konflik berarti persepsi mengenai kepentingan. ${ }^{3}$ Bentuk pertentangan alamiah yang dihasilkan oleh individu atau kelompok karena mereka yang terlibat memiliki perbedaan sikap, kepercayaan, nilai atau kebutuhan.

Oleh Liliweri ${ }^{4}$ konflik dirumuskannya sebagai berikut: Pertama, bentuk pertentangan alamiah yang dihasilkan oleh individu atau kelompok, karena mereka yang terlibat memiliki perbedaan sikap, kepercayaan, nilai atau kebutuhan. Kedua, hubungan pertentangan antara dua pihak atau lebih (individual atau kelompok) yang memiliki sasaran-sasaran tertentu namun diliputi pemikiran, perasaan atau perbuatan yang tidak sejalan. Ketiga, pertentangan atau pertikaian karena ada perbedaan dalam kebutuhan, nilai, motivasi pelaku atau yang terlibat di dalamnya. Keempat, sesuatu proses yang terjadi ketika satu pihak secara negative memengaruhi pihak lain, dengan melakukan kekerasan fisik yang membuat perasaan dan fisik orang lain terganggu. Kelima, bentuk pertentangan yang bersifat fungsional, karena pertentangan semacam itu mendukung tujuan kelompok dan membarui tampilan, namun disfungsional karena menghilangkan tampilan kelompok. Keenam, proses mendapatkan monopoli ganjaran kekuasaan, pemilikan dengan menyingkirkan atau melemahkan para pesaing. Ketujuh, suatu bentuk

\footnotetext{
${ }^{2}$ SN Kartika Sari, (ed), Mengelola Konflik, Keterampilan, dan Strategi untuk Bertindak, British Council, Jakarta, 2010, hlm.4.

${ }^{3}$ Pruit Dean, Rubin Jeffrey Rubin, Teori Konflik Sosial. Yogyakarta : Pustaka Pelajar, 2004, hlm.9.

${ }^{4}$ Liliweri, Alo. Prasangka dan Konflik: Komunikasi Lintas Budaya Masyarakat Multikultural, Lkis, Yogyakarta, 2005, hlm.249-250.
} 
perlawanan yang melibatkan dua pihak secara antagonis. Kedelapan, kekacauan ransangan kontradiktif dalam arti individu.

\section{B. Dampak Konflik}

Secara teoritis konflik atau sengketa dapat menimbulkan dampak negatif5. Dampak negatif adanya konflik atau sengketa antara lain terganggunya keserasian hubungan sosial, merusak tujuan bersama, menimbulkan kebencian dan kebingungan, dan mengurangi kepercayaan serta membangkitkan emosi. Tahap pra konflik atau tahap keluhan, mengacu kepada keadaan atau kondisi yang oleh seseorang atau suatu kelompok dipersepsikan sebagai hal yang tidak adil dan alasan-alasan atau dasardasar dari adanya perasaan itu. Pelanggaran terhadap rasa keadilannya itu dapat bersifat nyata atau imajinasi saja, tergantung pada persepsi dari pihak yang merasakan ketidakadilan bersangkutan.

Dalam hal ini yang penting adalah merasakan bahwa haknya dilanggar atau mereka diperlakukan dengan salah. Simon Fisher, dkk $^{6}$ mengemukakan teori yang menyebabkan terjadinya konflik dalam masyarakat antara lain: Teori hubungan masyarakat menyebabkan adanya kelompok yang berlawanan sehingga muncul permusuhan, dan teori kebutuhan manusia menyebabkan terjadinya konflik karena tidak terpenuhi atau terhalanginya kebutuhan dasar manusia baik fisik maupun mental. Secara umum, akibat konflik adalah :

a. Akibat positif, dalam bentuk manfaat yang diperoleh melalui konflik yaitu; 1) membantu meningkatkan solidaritas in-group (meningkatkan kohesivitas kelompok) dalam bentuk memperbaiki kepaduan integritas, 2) membantu fungsi komunikasi, 3)

${ }^{5}$ Coser, Lewis, Sosiologi Konflik dan Isu-Isu Konflik Kontemporer. Jakarta. PT. Raja Grafindo Persada, 2009.

${ }^{6}$ Fisher, Simon, dkk, Mengelola Konflik: Ketrampilan \& Strategi Untuk Bertindak. The British Council. Jakarta, 2001. 
memperjelas posisi, 4) merangsang kelompok untuk mencari asumsiasumsi untuk mengambil keputusan/mengambil tindakan yang tepat, 5) mendamaikan kelompok-kelompok yang saling bersaing, 6) dapat menemukan ide-ide yang lebih baik, 7) memunculkan isu-isu dan harapan-harapan yang terpendam, 8) memperjelas batas-batas dan norma-norma kelompok, 9) mempertegas tujuan yang hendak dicapai, 10) mengarahkan pihak-pihak yang sedang berjuang untuk mengekspresikan identitas, 11) mengurangi ketidakpastian dengan menjaga batas-batas kelompok dan 12) merangsang untuk menemukan nilai-nilai baru.

b. Akibat negatif dalam bentuk kerugian yang timbul karena pertengkaran, permusuhan, perbedaan, rusuh, ancaman, kesusahan atau kesulitan itu dapat digolongkan dalam bentuk fisik dan non fisik. Kerugian fisik yaitu 1) kematian, kecacatan umat manusia, 2) kehancuran berbagai sumber daya alam dan fasilitas. Kerugian non fisik yaitu 1) gangguan terhadap integrasi, 2) gangguan terhadap nilai-nilai yang bersifat positif, 3) timbulnya ketegangan dalam masyarakat, 4) menggangu proses pembangunan, dan sebagainya. ${ }^{7}$

\section{Cara Penyelesaian Konflik}

Untuk meyelesaikan sengketa, pada umumnya terdapat beberapa cara yang dapat dipilih. Cara-cara yang dimaksud adalah sebagai berikut : 1) Negosiasi. Negosiasi yaitu cara untuk mencari penyelesaian masalah melalui diskusi (musyawarah) secara langsung antara pihak-pihak yang bersengketa yang hasilnya diterima oleh pihak tersebut. 2) Mediasi. Mediasi yaitu upaya penyelesaian sengketa dengan melibatkan pihak ketiga yang netral, yang tidak

\footnotetext{
${ }^{7}$ Semuel Waileruny, Membongkar Konspirasi di Balik Konflik Maluku, Yayasan Obor Indonesia, Jakarta, 2011, hlm.34-35.
} 
memiliki kewenangan mengambil keputusan, yang membantu pihak-pihak yang bersengketa mencapai penyelesaian (solusi) yang diterima oleh kedua belah pihak. 3) Pengadilan. Pengadilan adalah lembaga resmi kenegaraan yang diberi kewenangan untuk mengadili, yaitu menerima, memeriksa, dan memutus perkara berdasarkan hukum acara dan ketentuan perundangundangan yang berlaku. 4) Arbitrase. Arbitrase merupakan cara penyelesaian sengketa di luar pengadilan, berdasarkan pada perjanjian arbitrase yang dibuat oleh para pihak, dan dilakukan oleh arbiter yang dipilih dan diberi kewenangan mengambil keputusan ${ }^{8}$

Sementara resolusi konflik ialah upaya menangani sebab-sebab konflik dan seraya kemudian berusaha membangun hubungan baru dan bisa tahan lama di antara kelompok-kelompok yang bermusuhan. Kebijakan publik (termasuk pula yang menyangkut resolusi konflik) yang dikeluarkan oleh pemerintah memiliki implikasi penting bagi perubahan sosial. Kebijakan pemerintah akan mampu memberikan nilai tambah pada kegiatan ekonomi, keadilan sosial politik, keamanan dan perdamaian di antara kelompokkelompok etnis, jika integrasi kelompok masyarakat dapat tercipta. Sebaliknya, kebijakan pemerintah yang bersifat diskriminatif atau berpihak pada kenyataannya akan mengakibatkan konflik antar kelompok di dalam masyarakat ataupun konflik antara masyarakat dengan pemerintah sendiri. ${ }^{9}$

Sementara Joel S. Migdal, ${ }^{10}$ proses resolusi konflik, bentuk hubungan Negara dan masyarakat sendiri dapat dilihat dari tiga indikator, yakni; 1) Compliance (izin, kepatuhan): penggunaan kepatuhan dengan cara menghidupkan sanksi untuk mengontrol masyarakat, 2) Participation

\footnotetext{
${ }^{8}$ Gatot Soemartono, Arbitrase dan Mediasi di Indonesia, Gramedia Pustaka Utama, Jakarta, 2006, hlm. 1-2.

${ }^{9}$ Lambang Trijono (ed), The Making of Ethnic \& Religious Conflict in Southeast Asia: Cases and Resolutions, CSPS Books, 2004.

${ }^{10}$ Joel S. Migdal, Strong Societies and Weak States (New Jersey, Princeton University Press, 1988.
} 
(pelibatan): partisipasi berkaitan dengan kesukarelaan (voluntary) dam aksi (action) dalam menjalankan kehidupan bernegara, 3) Legitimation (keabsahan), yang berkaitan dengan penerimaan bahkan persetujuan masyarakat dengan aturan main yang dibuat oleh negara.

\section{Peristiwa Konflik Etnis dan Agama di Indonesia}

Sebenarnya konflik itu dapat terjadi di manapun kita berada, entah konflik antar suku, ideologi, atau bahkan antar agama. Setiap dari manusia memiliki potensi konflik masing-masing seperti yang telah diuraikan dalam latar belakang. Semua ini tergantung pada kita, bagaimana kita menerima stimulus yang ada, merespon dari kekuatan stimulus yang timbul oleh suatu kejadian yang dapat menyebabkan perubahan potensi konflik menjadi sebuah konflik yang berbahaya. Patutnya kita dapat menganalisa dan memahami bagaimana penjelmaan tersebut dan kita dapat mencegah agar tak terjadi kesalahan yang sama. Manusia yang belajar adalah manusia yang tidak jatuh pada lubang yang sama.

Konflik yang terjadi yang berwujud wilayah rusuh di Indonesia merupakan akumulasi dari kerapuhan persatuan dan kesatuan warga masyarakat heterogen dalam satuan-satuan wilayah kebudayaan dengan kepentingan konspirasi kelompok-kelompok tertentu di dalam negeri serta pihak asing. Kepentingan itu dilaterbelakangi tujuan politik, ekonomi dan agama. Upaya itu tidak mencapai sasaran puncak karena ditingkat elit dan pelaksana pihak keamanan dan birokrasi mayoritas masih komit dengan negara kesatuan sehingga serius memperkecil zona konflik dan kefatalan pelbagai dampaknya. Masyarakat dari berbagai suku dan agama juga tidak memiliki basic yang kuat memasuki kancah konflik bahkan sebaliknya dari semula sudah terbiasa hidup rukun dan damai dalam pelbagai perbedaan. Namun begitu karena masyarakat telah semakin berpendidikan dan cerdas, ditambah dengan nuansa reformasi secara mencuatnya konsep HAM, mereka 
menginginkan agar pelbagai pihak yang terkait dengan pembangunan kehidupan mereka, seyogyanya mengikutsertakannya dalam merancang program itu sehingga sesuai sasaran.

Masyarakat adalah makhluk sosial yang selalu berinteraksi. Dalam interaksinya, manusia sering dihadapkan pada situasi konflik (pertentangan / pertikaian). Munculnya konflik sosial tidak terjadi dengan sendirinya dan tidak sesederhana yang bisa kita bayangkan. Banyak faktor yang dapat dikaji mengapa konflik tersebut muncul dipermukaan. Pada umumnya konflik merupakan suatu gejala sosial yang sering muncul dalam kehidupan bermasyarakat. Dalam sejarah Indonesiapun seringkali diwarnai dengan berbagai konflik, baik konflik yang terjadi antara bangsa Indonesia dengan para penjajah, maupun konflik yang terjadi diantara bangsa ini. Pada masa kemerdekaan dan reformasi, konflik-konflik sosial terjadi di Ambon, Nangroe Aceh Darussalam, Poso dan di berbagai daerah lainnya.

Mengingat begitu beragamnya latar belakang dan tingkat sosial masyarakat, maka persoalan hak dan kewajiban senantiasa muncul menjadi konflik sosial yang berkepanjangan dan terjadi di berbagai daerah. Konflik yang menggunakan simbol etnis, agama dan ras muncul yang mengakibatkan jatuhnya korban jiwa dan harta bagi pihak yang bertikai. Hal ini terjadi jika dalam hubungan tersebut terjadinya suatu kesenjangan status sosial, kurang meratanya kemakmuran serta kekuasaan yang tidak seimbang. Kepentingan dan keinginan-keinginan yang tidak lagi harmonis akan membawa masalah dalam hubungan antara individu atau kelompok yang satu dengan yang lainnya.

Keragaman adalah realitas Indonesia yang tidak bisa ditolak. Keragaman elemen yang membentuk masyarakat politik (negara) Indonesia terlihat jelas dalam sejarah berdirinya Negara Kesatuan Republik Indonesia (NKRI). Semboyan Bhineka Tunggal Ika (berbeda-beda namun tetap satu) secara jelas menyatakan bahwa keragaman Indonesia tidak bisa dihomogenisasi. 
Indonesia adalah satu dalam keragaman. Semboyan Bhineka Tunggal Ika itu telah mengantarkan Indonesia sebagai salah satu contoh negara yang mampu memelihara realitas keragamannya dan mendapatkan manfaat dari keragaman tersebut. Dalam hal keragaman agama, toleransi antarumat beragama merupakan modal sosial yang menjadi kunci keberhasilan Indonesia, dan harus terus dipelihara untuk menjaga keutuhan Indonesia.

Keragaman sosio-kultural di dalam suatu bangsa atau negara memiliki intensitas konflik yang lebih tinggi dibandingkan dengan negara-negara yang struktur sosialnya bersifat homogen. Heterogenitas suatu bangsa sering kali menimbulkan konflik antar suku, agama, ras dan antar golongan yang sering diistilahkan di Indonesia sebagai konflik suku, agama, ras dan aliran kepercayaan (SARA). Selain itu, gejala deferensiasi sosial (penggolongan sosial) jika tidak ditangani secara bijak akan menimbulkan kerawanan konflik sosial. Akan tetapi, di sisi lain keanekaragaman sosio-kultural suatu bangsa juga bisa menjadi kekayaan khazanah budaya bangsa dalam percaturan internasional, sehingga keanekaragaman sosial budaya juga berdampak pada keuntungan ekonomis jika dikelola dengan baik. Selain keragaman sosiokultural, ketimpangan ekonomi juga memicu di antara para anggota masyarakat.

Menurut Koentjaraningrat ${ }^{11}$ suatu kelompok adalah suatu kesatuan individu yang terikat antara lain : (a) Suatu sistem norma-norma yang mengatur kelakuan warga kelompok; (b) Suatu rasa kepribadian kelompok yang disadari semua warganya; (c) Aktivitas-aktivitas berkumpul dari wargawarga kelompok secara berulang-ulang; (d) Suatu sistem hak dan kewajiban yang mengatur interaksi antar warga kelompok; (e) Suatu pimpinan atau pengurus yang mengorganisasi aktivitas-aktivitas kelompok; (f) Suatu sistem

\footnotetext{
${ }^{11}$ Koentjaraningrat,. Metode-metode Penelitian Masyarakat, Jakarta: Penerbit PT. Gramedia, 1981, hlm. 109.
} 
hak dan kewajiban bagi para individunya terhadap sejumlah harta produktif, harta konsumtif, atau harta pusaka tertentu. Salah satu kelompok tersebut adalah kekerabatan (klan). Klan besar (kelompok marga) merupakan suatu kelompok kekerabatan yang terdiri dari semua keturunan dari seorang nenek moyang yang diperhitungkan melalui garis keturunan sejenis ialah keturunan warga-warga pria maupun wanita.

Beberapa faktor yang memungkinkan konflik etnis muncul ke permukaan menjadi konflik terbuka adalah, pertama, perubahan konstelasi politik pada masa reformasi dan iklim kebebasan yang dijunjung tinggi menjadi ladang subur untuk mengungkapkan keresahan beberapa kelompok etnik. Kedua, tidak meratanya pembangunan diberbagai wilayah di Indonesia, disadari atau tidak terpolarisasi berdasarkan kelompok etnik. Ketiga, tidak dapat dipungkiri bahwa dalam masyarakat Indonesia, identitas etnik menjadi faktor penting dalam kehidupan masyarakat, terutama perdesaan. ${ }^{12}$

Penyebab konflik antar etnis dengan beberapa kasus konflik etnis yang pernah terjadi diberbagai tempat dan pemikiran yang berkembang dalam masyarakat ${ }^{13}$. Pertama, Dilema keamanan kelompok etnik. Segala usaha untuk meningkatkan keamanan yang dilakukan suatu kelompok sehingga menimbulkan reaksi balik dari kelompok lain dan apada akhirnya membuat kelompok tersebut merasa kurang aman. Teori menjelaskan adanya otoritas perang yang dapat terjadi jika suatu kelompok memiliki rasa tidak percaya pada kelompok etnis lain dan rasa tidak percaya ini berkembang menjadi mobilisasi kekuatan yang menegaskan kecurigaan antar kelompok yang juga menunjukkan maksud agresif, kondisi pemerintahan yang lemah, pemerintah pusat menjadi bagian dari konflik, situasi perubahan yang mendadak. Kedua,

\footnotetext{
${ }^{12}$ Wirutomo, Paulus. "Menggagas Indonesia Masa Depan?” Makalah yang dipresentasikan dalam Dies Natalis UI, 2012. Lihat Konflik Etnik di Indonesia : Satu Kajian Kes di Bandararaya Medan oleh Subanindyo Hadiluwih, USU Press, 2008 dan Konflik Komunal di Indonesia saat ini, INIS, Jakarta, 2003.

${ }^{13}$ Ibid
} 
Perlindungan status. Kelompok berperang memepertahankan status sehingga mucul ketakutan bahwa nilai-nilai dan cara hidup serta institusi kelompok etnis tertentu bisa menjadi sub-ordinat kelompok etnis lain. Ketiga, Ambisi hegemoni. Suatu kelompok yang berkuasa tidak cukup puas dengan bertahannya nilai-nilai budaya dan institusi mereka, tetapi ingin menjadi kelompok dominan yang menuntut perlakuan tertentu dari pemerintah. Keempat, Aspirasi kaum elit. Adanya ambisi dari elit kelompok etnik tertentu untuk mendapatkan dan mempertahanakan kekuasaan dengan menggunakan isu-isu ketakukan, kebencian, dan ambisi kelompok etnik.

Sebagai sebuah negara yang multietnis di Indonesia sudah banyak terjadi kasus kekerasan antar-etnis, terutama antara etnis lokal dengan etnis pendatang, serta sudah memakan banyak korban jiwa, seperti di Sambas Kalimantan Barat yaitu konflik antar etnik Dayak dan Madura. Akar terjadinya konflik antara etnik Dayak dan Madura berawal dari adanya perbedaan sosial budaya yang melahirkan perbedaan pemahaman, sikap dan prilaku yang dapat memunculkan pandangan negatif, kebencian dan antipati, sehingga peristiwa yang semula sepele yang hanya dilakukan oleh individu berubah menjadi penyulut meledaknya konflik yang melibatkan etnik. Begitu pula yang terjadi di Ambon Maluku yaitu konflik yang diawali oleh pertikaian antara dua individu berbeda etnis. Pertikaian tersebut melebar menjadi konflik antar pendatang dan penduduk lokal. Akhirnya konflik bergeser menjadi konflik bernuansa agama, yaitu antara meraka yang beragama Islam (Salam) dengan Protestan dan Katolik (Sarani).

Bahwa kerusuhan etnik berakar dari kesenjangan sosial-ekonomi dan merupakan protes budaya yang memberikan petunjuk kuat bahwa tatanan sosial dalam kehidupan majemuk telah dilanggar dan dihancurkan. Usman 
Pelly ${ }^{14}$ menyebutkan dalam banyak kasus, konflik dan kekerasan bernuansa etnik, agama yang pecah di tengah masyarakat lebih dilatarbelakangi kondisi sosial, ekonomi, dan politik daripada perbedaan keyakinan. Bahkan agama, etnik, ras, suku sering diperalat sebagai faktor legitimasi untuk menggerakkan emosi dan solidaritas primordial. Sejarah membuktikan, manipulasi agama, etnik, ras, suku untuk kepentingan sosial, ekonomi dan politik sangat membahayakan kehidupan suatu negara bangsa. Agama, etnik, ras sering dijadikan alat pemicu kekerasan. Meskipun ada faktor-faktor lain yang selalu berkelindan di ketiak agama, etnis, ras, suku, sehingga seakan ia telah mendapatkan legitimasi dari identitas sosial.

Sulaeman Munandar ${ }^{15}$ menjelaskan bahwa konflik sosial sering muncul belakangan ini merupakan indikator dari proses transformasi sosial yang sedang berlangsung, berupa representasi benturan nilai sosial dan nilai agama serta sedang terjadi pergeseran setting penguasaan sumber daya strategis berupa kekuasaan atau politik dan ekonomi. Mungkin adanya pergeseranpergeseran peran kelompok dalam masyarakat yang dapat menimbulkan pertentangan dan kontradiksi atau disorganisasi struktur, kultur dan pola relasi antar individu dan kelompok.

Kelompok sosial sendiri adalah suatu kelompok yang tinggal bersama dalam waktu yang cukup lama dan menyepakati dengan nilai-nilai dan moral yang ada dalam kehidupannya. Jika ada suatu kelompok sosial lain yang ingin mendominasi kelompok tersebut, maka akan terjadi konflik karena potensi konflik tersebut telah terpicu akan pendominasian itu. Ini dikarenakan Indonesia belum mengfungsikan unsur-unsur bangsa menjadi suatu integrasi yang kuat. Keberagaman agama, suku, dan budaya merupakan salah satu

\footnotetext{
${ }^{14}$ Pelly, Usman, 1999. Akar Kerusuhan Etnik di Indonesia: Suatu Kajian Awal Konflik dan Disintegrasi Nasional di Era Reformasi. Dalam Jurnal Antropologi Indonesia No. 58, 1999, hlm.34.

${ }^{15}$ Munandar Sulaeman, Konflik Multi Dimensi Masyarakat Tasikmalaya (Kajian Kerusuhan 1966 dan Pasca Kerusuhan 1997-2001), Disertasi Program Doktor Dalam Sosiologi Universitas Indonesia, 2003.
} 
potensi konflik yang sangat menonjol di negara Indonesia yang kaya akan budaya. Sekarang bagaimana dengan keberagaman tersebut Indonesia dapat berintegrasi dengan kuat dan membentuk suatu kesatuan yang kuat agar tidak terjadinya konflik-konflik yang tidak diinginkan.

Suparlan ${ }^{16}$ mengemukakan bahwa faktor perbedaan budaya yang tercermin dalam perbedaaan sistem nilai budaya dan sistem orientasi budaya suatu masyarakat yang berpotensi menimbulkan konflik sosial. Perbedaan sistem nilai dan orientasi budaya inilah yang selanjutnya muncul dalam sikap, mental, prilaku, dan perbuatan anggota atau masyarakat etnik tertentu yang bertentangan dengan kelompok etnik lain. Bila kita melihat peta konflik pada masyarakat Indonesia maka terdapat beberapa jenis konflik internal berdasarkan pihak yang terlibat, seperti : konflik komunal (antar kelompok etnis); konflik komunal (antar penduduk lokal dan pendatang); gerakan separatis (kelompok etnis dengan negara atau

Kerusuhan dan pertikaian yang terjadi di berbagai daerah di Indonesia menunjukkan antara lain kurangnya kemampuan pemerintah dalam mengatasi penyebab terjadinya konflik sosial antar masyarakat. Konflik muncul dengan menggunakan simbol-simbol etnis, agama, dan ras. Hal ini kemungkinan terjadi akibat adanya akumulasi "tekanan" secara mental, spiritual, politik sosial, budaya dan ekonomi yang dirasakan oleh sebagian masyarakat. Seperti halnya konflik antar etnis yang terjadi di Kalimantan Barat, kesenjangan perlakuan aparat birokrasi dan aparat hukum terhadap Suku Asli Dayak dan Suku Madura menimbulkan kekecewaan yang mendalam yang meledak dalam bentuk konflik-konflik horizontal. Masyarakat Dayak yang termarjinalisasi semakin terpinggirkan oleh kebijakan-kebijakan yang diskriminatif yang mengeksploitasi kekayaan alam mereka. Sementara penegakan hukum terhadap salah satu kelompok tidak berjalan sebagaimana mestinya.

\footnotetext{
${ }^{16}$ Suparlan, Parsudi, Interaksi Antaretnik di Beberapa Provinsi di Indonesia. Jakarta; Depdikbud, 1989.
} 
Kebudayaan yang berbeda seringkali dijadikan dasar penyebab timbulnya suatu konflik pada masyarakat yang berbeda sosial budaya. Demikian juga yang terjadi pada konflik Dayak dan Madura yang terjadi pada akhir tahun 1996 yaitu terjadinya kasus Sanggau Ledo, Kabupaten Bengkayang (sebelum pertengahan tahun 1999 termasuk Kabupaten Sambas), di Kalimantan Barat. ${ }^{17}$ Dalam berkomunikasi penduduk yang heterogen ini menggunakan bahasa Indonesia atau Melayu sebagai bahasa sehari-hari. Tetapi karena tingkat pendidikan mereka rendah, kebanyakan mereka memakai bahasa daerahnya masing-masing. Dengan demikian seringkali ditemui kesalahpahaman di antara mereka. Hukum adat memegang peranan penting bagi orang Dayak. Perilaku dan tindakan masyarakat pendatang khususnya orang Madura menimbulkan sentimen sendiri bagi orang Dayak yang menganggap mereka sebagai penjarah tanah mereka.

\section{E. Kekerasan Antarkelompok Agama : Memperkuat Toleransi}

Agama adalah aturan atau tata cara hidup manusia dalam hubungannya dengan Tuhan dan sesamanya. Itulah definisi sederhananya. Tetapi definisi yang sempurna dan lengkap tak pernah dapat dibuat. Agama dapat mencakup tata tertib upacara, praktik pemujaan, dan kepercayaan kepada Tuhan, Sebagian orang menyebut agama sebagai tata cara pribadi untuk dapat berhubungan langsung dengan Tuhannya. Agama juga disebut pedoman hidup manusia, pedoman bagaimana harus berpikir, bertingkah laku dan bertindak, sehingga tercipta hubungan yang serasi antarmanusia dan hubungan erat dengan Yang Maha Pencipta. Ditinjau dari definisi yang sederhana, di dunia ini terdapat ribuan agama. Namun banyak negara hanya

\footnotetext{
${ }^{17}$ Alqadarie Syarief I. (2000). Laporan Akhir Hasil Penelitian Pertikaian antar Komunitas Madura Kalimantan Barat dengan Dayak 1996/97 dan antara Komunitas Madura Sambas dengan Melayu Sambas Tahun 1998/1999 di Kalimantan Barat. Kerjasama Yayasan Ilmu-ilmu Sosial Jakarta-dengan Fisipol Untan-Pontianak. Tentang kerusuhan di Maluku dijelaskan oleh John Pieris, Tragedi Maluku : Sebuah Krisis Peradaban, Yayasan Obor Indonesia, Jakarta, 2004.
} 
mengakui beberapa agama tertentu. Delapan agama besar di dunia adalah Yahudi, Hindu, Buddha, Konghucu, Taoisme, Shinto, Kristen, Islam. Dengan demikian dapat dipahami bahwa determinan (faktor penyebab) intoleransi antaragama sesungguhnya tidak berasal dari agama itu sendiri. Adalah sulit untuk memahami bagaimana agama yang berisi ajaran-ajaran yang baik itu di dalam dirinya sendiri mengandung konflik.

Orientasi beragama bisa menjadi referensi bagaimana cara seseorang mempraktikkan atau hidup menampakkan kepercayaan dan nilai religiusnya. Orientasi religius ini terbagi dua, yakni orientasi-intrinsik dan orientasi ekstrinsik. Orientasi intrinsik sebagai motivasi untuk mencapai tujuan agama itu sendiri. Orang yang termasuk tipe orientasi religius ini, hidupnya menampakkan keyakinan agama untuk kepentingan yang diyakininya. Komitmen terhadap nilai yang diyakini lebih penting dibandingkan ibadah yang tampak. Orang religius bertipe ini secara mendalam terlibat keyakinan dan nilai yang dianut dengan cara mau berkorban bahkan mengalahkan kepentingan dirinya sendiri . Motivasi agama pada orang tersebut menjadi inspirasi langkahlangkah kehidupannya. Orientasi religius - intrinsik mengimplikasikan agama sebagai motivasi dan sumber yang memberi pengharapan dalam menjalani kehidupan. ${ }^{18}$

Sementara orang yang tergolong religius ekstrinsik menggunakan agama sebagai alat mencapai yang bukan tujuan agama. Motif orientasi religius ekstrinsik hanya sebatas nilai dan keyakinan sosial atau yang tampak. Tipe ini adalah gambaran orang yang mengejar tujuan untuk kepentingan pribadi dan menggunakan agama untuk mencapai kedudukan sosial dan kekuasaan. Religius ekstrinsik dikatakan sebagai pertanda kurang dewasanya

\footnotetext{
${ }^{18}$ Azyumardi Azra (Editor) .1998. Agama Dalam Keragaman Etnik Di Indonesia. Jakarta: Badan Penelitian Dan Pengembangan Agama Departemen Agama RI.
} 
dalam beragama dibandingkan yang intrinsik. Berdasarkan uraian di atas jelaslah bahwa konflik antaragama diduga dapat dipengaruhi oleh orientasi agama yang ekstrinsik, atau menggunakan agama sebagai alat mencapai tujuan yang bukan tujuan agama itu sendiri, melainkan kepentingan pribadi atau menggunakan agama untuk mencapai kedudukan sosial dan kekuasaan.

Toleransi merupakan sikap dan tindakan yang saling memberikan peluang atau kesempatan kepada pihak lain untuk melakukan sesuatu, sehingga benih-benih pertentangan antar individu atau antarkelompok dapat dicegah. Dari berbagai definisi di atas dapat disimpulkan bahwa toleransi adalah suatu sikap dan tindakan yang bukan hanya membutuhkan kesadaran, tetapi juga semangat, gairah, perjuangan dalam bersikap toleran demi hidup bersama yang lebih baik dengan cara memberikan peluang atau kesempatan pada kelompok/umat agama lain untuk melakukan sesuatu untuk terciptanya hubungan antarmasyarakat yang harmonis dan rukun.

Toleransi antarkelompok agama merupakan isu yang kerap menjadi perhatian besar di Indonesia, khususnya di era reformasi. Konflik antaragama di banyak tempat bisa dikategorikan sebagai bencana nasional, karena membahayakan persatuan dan kesatuan nasional. Konflik dalam kategori bencana nasional ini bukan hanya mengakibatkan korban materi tetapi juga, korban luka-luka dan korban meninggal dunia. Wajar saja jika konflik antaragama yang terus berlangsung hingga saat ini menjadi perhatian banyak pihak di negeri ini. Toleransi yang awalnya menjadi modal sosial untuk terciptanya integrasi bangsa pada era reformasi kerap mengalami pasang surut. Akibatnya proses integrasi bangsa bukan hanya mengalami hambatan, tetapi kecurigaan antarkelompok semakin kuat, bahkan tidak jarang hanya gara-gara karena persoalan sepele, konflik antaragama bisa meletus.

Tentu masih segar dalam ingatan kita peristiwa berdarah yang terjadi dalam kurun 1998 - 2000 di Ambon, Maluku. Saat itu pecah kerusuhan berkepanjangan antar-kelompok masyarakat beragama yang melibatkan 
kelompok Kristen dengan Islam. Konflik yang berlangsung bertahun-tahun dan memakan banyak korban jiwa dan harta benda itu padahal bermula dari konflik antara preman asal Sulawesi Selatan dengan sopir angkutan kota. Kemudian meluas menjadi konflik antara kelompok masyarakat Ambon dan kelompok Masyarakat Bugis, Buton dan Makassar. Karena konflik tersebut kemudian membawa-bawa agama, maka kemudian menjadi konflik antara kelompok masyarakat Kristen Ambon dengan kelompok masyarakat Islam Ambon. Konflik ini menjadi salah satu konflik terbesar dan terlama di negeri ini, dan dapat dikatakan sebagai bencana nasional yang mengakibatkan hilangnya banyak nyawa, serta harta benda. Konflik yang membawa-bawa nama agama juga terjadi di Maluku Utara yang melibatkan dua kelompok masyarakat yang berbeda agama

Konflik dalam skala besar juga terjadi di Poso, Sulawesi Tengah. Laporan jurnalistik menyebutkan konflik Poso sebagai tragedi tiga babak. Pertama tanggal 25-30 Desember 1998; Kedua 15-21 April 2000; Ketiga, tanggal 23 Mei - 10 Juni 2001. Ditilik dari sisi dinamika kelompok (in group-out group), kerusuhan ini merupakan konflik horizontal antara kelompok Islam dan Kristen. Konflik bermula dari perkelahian antarpemuda (kriminal) berkembang menjadi kerusuhan bernuansa SARA yang tidak terkendali, mengakibatkan tumpulnya pemerintahan, perekonomian, transportasi dan aktivitas masyarakat. Agama bukan merupakan pemicu utama, tapi lebih berperan sebagai faktor pengiring yang datang belakangan, dimanfaatkan selaku penggalang solidaritas.

Belum lama ini, konflik yang sama juga sempat melanda masyarakat Tolikara, Papua, tepatnya pada 17 Juli 2015 lalu. Konflik ini diduga ada kaitannya dengan agama, karena menyasar kelompok agama tertentu dan juga rumah ibadah. Dalam peristiwa ini bukan hanya gedung bangunan yang menjadi sasaran amuk massa, tapi juga menyebabkan seorang warga meninggal dunia, dan beberapa orang lainnya terluka parah. Belum tuntas 
persoalan ini, konflik antarwarga berbeda agama meletup di Singkil, Aceh, pada pertengahan Oktober 2015. Dengan alasan tidak memiliki izin, beberapa gereja menjadi sasaran amuk massa. Selanjutnya massa menuntut agar tempat-tempat ibadah umat kristiani tersebut ditutup selamanya. Pada peristiwa ini bukan hanya rumah ibadah yang dibakar, namun juga ada korban meninggal dan luka-luka, dan ribuan orang mengungsi.

\section{F. Penutup}

Kita harus mengakui, Indonesia yang sejak dulu terkenal dengan keramahtamahannya, telah berubah menjadi negara yang kerap diwarnai kekerasan bernuansa agama. Kondisi ini semakin diperparah oleh oknumoknum atau kelompok tertentu yang dengan sengaja “menjual” agama untuk hal-hal yang sama sekali tidak ada kaitannya dengan agama itu sendiri. Singkatnya, kemajemukan masyarakat Indonesia kini bisa jadi bukan lagi menjadi modal dasar pembangunan, tapi justru menjadi beban berat bagi bangsa Indonesia. Wassalam.

\section{DAFTAR PUSTAKA}

Alqadarie Syarief I. Laporan Akhir Hasil Penelitian Pertikaian antar Komunitas Madura Kalimantan Barat dengan Dayak 1996/97 dan antara Komunitas Madura Sambas dengan Melayu Sambas Tahun 1998/1999 di Kalimantan Barat. Kerjasama Yayasan Ilmu-ilmu Sosial Jakarta-dengan Fisipol Untan-Pontianak, 2000.

Coser, Lewis. Sosiologi Konflik dan Isu-Isu Konflik Kontemporer. Jakarta. PT. Raja Grafindo Persada. 2009

Fisher, Simon, dkk. Mengelola Konflik: Ketrampilan \& Strategi Untuk Bertindak. The British Council. Jakarta, 2001.

Gatot Soemartono, Arbitrase dan Mediasi di Indonesia, Gramedia Pustaka Utama, Jakarta, 2006. 
Hadiluwih, Subanindyo, USU Press, 2008 dan Konflik Komunal di Indonesia saat ini, INIS, Jakarta, 2003.

Joel S. Migdal, Strong Societies and Weak States (New Jersey, Princeton University Press, 1998.

John Pieris, Tragedi Maluku : Sebuah Krisis Peradaban, Yayasan Obor Indonesia, Jakarta, 2004.

Koentjaraningrat, Metode-metode Penelitian Masyarakat, Jakarta: Penerbit PT. Gramedia, 1985.

Lambang Trijono (ed), The Making of Ethnic \& Religious Conflict in Southeast Asia: Cases and Resolutions, CSPS Books, 2004.

Liliweri, Alo. Prasangka dan Konflik: Komunikasi Lintas Budaya Masyarakat Multikultural, Lkis, Yogyakarta, 2005.

Munandar Sulaeman, Konflik Multi Dimensi Masyarakat Tasikmalaya (Kajian Kerusuhan 1966 dan Pasca Kerusuhan 1997-2001), Disertasi Program Doktor Dalam Sosiologi Universitas Indonesia, 2003.

Pelly, Usman, Akar Kerusuhan Etnik di Indonesia: Suatu Kajian Awal Konflik dan Disintegrasi Nasional di Era Reformasi. Dalam Jurnal Antropologi Indonesia No. 58, 1998.

Pruit Dean, Rubin Jeffrey Rubin, Teori Konflik Sosial. Yogyakarta : Pustaka Pelajar, 2004.

Rauf, Maswadi, Konsensus Politik. Jakarta: Direktoral Jenderal Pendidikan Tinggi Departeman Pendidikan Nasional, 2001.

Semuel Waileruny, Membongkar Konspirasi di Balik Konflik Maluku, Yayasan Obor Indonesia, Jakarta, 2011.

SN Kartika Sari, (ed), Mengelola Konflik, Keterampilan, dan Strategi untuk Bertindak, British Council, Jakarta, 2010.

Suparlan, Parsudi, Interaksi Antaretnik di Beberapa Provinsi di Indonesia. Jakarta; Depdikbud, 1989

Wirutomo, Paulus. "Menggagas Indonesia Masa Depan?" 
Makalah yang dipresentasikan dalam Dies Natalis UI, 2012. Lihat Konflik Etnik di Indonesia: Satu Kajian Kes di Bandararaya Medan 